\title{
The dark chocolate against angiogenesis?
}

\begin{abstract}
Aimed to study the connection of dark chocolate and different phases of angiogenesis resulting in cancer pathogenesis. Dark chocolate is derived from cocoa (cacao), may have speckled polyphenol and flavonoids contents retains different levels of antioxidant abilities. The existence of methylxanthines, peptides and polyphenols like flavonoids may synergistically augment or diminish antioxidant properties of dark chocolate (cocoa). The Dark chocolate has certain capacity to famish tumors development and fighting against angiogenesis.
\end{abstract}

Keywords: dark chocolate, angiogenesis, antioxidant
Volume 2 Issue 5 - 2015

\author{
Sami Ullah Khan, ' Abdul Qayyum, ${ }^{2}$ \\ Salahudin, ${ }^{3}$ Izharullah, ${ }^{4}$ Mahmood \\ AkhtarKayani, ${ }^{5}$ Faraz Arshad Malik ${ }^{5}$ \\ 'Department of Biosciences, COMSATS Institute of Information \\ Technology, Pakistan \\ 2Department of Languages, Government Degree College, \\ Pakistan \\ ${ }^{3}$ Health Services Academy, Pakistan \\ ${ }^{4}$ Department o Pharmacy, Malakand University, Pakistan \\ ${ }^{5}$ Department of Biosciences, Comsats University of Information \\ Technology, Pakistan
}

Correspondence: Sami Ullah Khan, Department of

Biosciences, COMSATS Institute of Information Technology, Islamabad, Pakistan, Tel 79872I67595,

Emailskmwt2003@gmail.com

Received: March 28, 2015 | Published: May 26, 2015

\section{Introduction}

Timeline of cocoa arose in 2,000 B.C, the date recognized by historians to hoariest swallowing cups and plates that has endlessly revealed in Latin America, Ulúa valley (Honduras), where cocoa has a vital role. Cacao is plagiaristic from Olmec and consequent Mayan languages kakaw, whereas chocolate-associated tenure cacahuatl is Nahuatl, Aztec language, resulting from Olmec-Mayan etymology. ${ }^{1}$ An elusive tree, cacao is merely grown in rainy forests in tropics, ordinarily on large farmsteads, where it essentially sheltered from passionate sunlight and wind. Different parts of cacao tree have been consumed; explicitly cocoa beans primed as chocolate, cocoa butter, cocoa bark, cocoa pulp, cocoa flower and cocoa leaf. In 1505, Spanish fetched Cocoa to Europe. In 1653, in Europe cocoa used in terms of medicine comparatively than that of pleasant foodstuff. Practice of chocolate was renowned as an inspiring vigorous utility of spleen and other gastrointestinal functions. Revisions upon wellbeing profits of the cocoa food stuffs have been steered over past span with a topmost emphasis on deteriorating diseases. These doles could be in result of their momentous amounts of catechin and epicatechin (flavonoid monomers) which have copious favorable biological actions in anticipation of angiogenesis and cancer. ${ }^{2}$ Most of revisions have scrutinized the charities of flavonoids in cocoa as well as cocoa foodstuffs towards health doles, but it should be renowned that cocoa and its foodstuffs are also ironic in methylxanthines (theophylline, caffeine, and Theo bromine). ${ }^{3}$ Revisions have confirmed which methylxanthines can retain equally positive and negative vigor effects (Table 1). ${ }^{4}$

\section{Polyphenols}

Dark chocolate prepared from cocoa that is opulent in polyphenols. Polyphenols are strong inhibitors of COX-2. ${ }^{5} \mathrm{COX}-2$ is known as an enhancer of carcinogenesis in various organs. Hereafter, assays of COX-2 expression may be used to monitor process of carcinogenesis, and suppression of COX-2 expression has become an important target for treatment and prevention of various types of cancers. ${ }^{6-8}$
In 1909, vanDorsen and Ultée identified core polyphenol present in cocoa known as "Kakaool". ${ }^{9}$ Uphold studies specified that this was a catechin, which was inaccurately entitled as 1-acacatechin found in cutch fabricating acacias. ${ }^{10}$ In 1940, it believed that "Kakaool" possibly symbolized 1-epicatechin also seen in Acacia catechu. ${ }^{11}$ Cocoa and cocoa bean consists of four different brands of catechins of that (-)-epicatechin (92\%), ${ }^{12}$ un-fermented cocoa bean consists tannin and catechin. ${ }^{10}$ Alongside these composites, cocoa has also leucoanthocyanins, which found as glycosides. Correspondingly, cocoa bean also consists of two cyanidin glycosides as well as at least 3-leucocyanidins (procyanidin) composites. Cocoa bean has also epicatechindimeric and leucocyanidin. ${ }^{12}$ The foremost constituents of cocoa extracts are (-)-epicatechin, catechin, anthocyanins, leucocyanidins, chlorogenic acid, and p-coumarylquinic acid. Flavonols are the chief composites in cocoa and cocoa powder. Epicatechinis is chief component in all chocolates, (in ration 1:0.1), related to catechin. ${ }^{13}$ The antioxidant activities of polyphenols are due to their chemical structures..$^{14}$ Dark Chocolates has large amounts of polyphenol ingredients, like; Quercetin (including its glucoside), (-)-epicatechin (EC), (+)-catechin, deoxyclovamide, clovamide, trans-resveratrol its glucoside and procyanidin..$^{14,15}$

\section{Methylxanthines}

Methylxanthines present in cocoa includes; caffeine, theophylline, and theobromine. ${ }^{3}$ In dark chocolates, methylxanthines are liable for cravings of chocolate. ${ }^{16}$ Theobromine, the foremost methylxanthine found in cocoa, which is $4 \%$, and caffeine is up to $0.2 \% .{ }^{17}$ The percentage of theobromine is higher than that of theophylline in cocoa beans. ${ }^{17}$ Major Methylxanthine in cocoa and cocoa foodstuffs is caffeine. ${ }^{3}$ The studies specified that bioactivity as well as importance of cocoa and cocoa foodstuffs were due to polyphenols. ${ }^{13}$ It has been identified that theobromine has therapeutic results on cancer and angiogenesis, like; theobromine potentially obstruct angiogenesis prompted by ovarian cancerous cells through mechanism to reticence the production of VEGF (vascular endothelial growth factor). ${ }^{18}$ 
Table I Components of dark chocolate ${ }^{4}$

\begin{tabular}{|c|c|c|}
\hline Class & Sub Class & Polyphenol \\
\hline Anthoxanthins & \multirow{3}{*}{$\begin{array}{l}\text { Flavonols } \\
\text { (Flavan-3- } \\
\text { ols) }\end{array}$} & Myricetin, Fisetin, Quercetin, Kaempferol, Isorhamnetin \\
\hline Flavanols & & $(+)$-Catechin, (-)-Epicatechin, (-)-Epicatechin 3-gallate, Morin, (-)-Epigallocatechin, \\
\hline & & (-)-Epigallocatechin-3-gallate, (+)-Gallocatechin, Procyanidins, Prodelphinidins \\
\hline Tannins & & Catechin polymers, Epicatechin polymers, Ellagitannins, Proanthocyanidins, Casuarictin, Sanguin H6, Tannic acids \\
\hline
\end{tabular}

\section{Peptides}

Cocoa contains large number of proteins. Peptides in cocoa are mainly accountable for flavor. ${ }^{19,20}$ It consists of four different kinds of proteins, which are, albumins, prolamin, globulins, and glutelin. Among them albumin is in foremost protein ratio. ${ }^{21}$ Protein Albumin is $52 \%$ whereas globulin is about $43 \%$ of protein present in cocoa bean. ${ }^{22}$

\section{Angiogenesis}

The process of developing new blood vessels resulting from presurviving blood vessels called as angiogenesis..$^{23}$ It is vigorous and common process in wound healing, development and growth. It is important for tumor conversion from resting condition into malignant, resulting in usage of angiogenesis inhibitors. ${ }^{24}$

\section{Types}

Sprouting angiogenesis

This type of angiogenesis carried out in different phases that are; biological signaling phase in which angiogenic factors motivate receptors located on surface of endothelial cells in blood vessels that are pre-existing, these motivated endothelial cells instigate to proclamate enzymes known proteases which worsen cellar membrane that allowing endothelial cells and seepage them from paternal vessel walls. This mechanism results in proliferation of endothelial cells into adjacent matrix to form sprouts, after which endothelial cells proliferate into adjacent matrix to form solid sprouts linking nearby vessels. ${ }^{25,26}$

\section{Intussusceptions angiogenesis}

Intussusceptions angiogenesis is also called splitting angiogenesis. During this type of angiogenesis, capillary wall spreads into lumen results in splitting of single vessel into two. Its mechanism takes place in four different phases. In first phase of Intussuscepted angiogenesis, two conflicting capillary walls institute a region of communication followed by second phase in which the endothelial cell confluences are rationalized that allow vessel bilayer to Puncture to permit growth factor and thus cells are breach in lumen. In third phase, there is formation of core between two newly developed vessels at region of connection occupied by pericytes and myofibroblasts. Cells initiate to lay collagen gibers within core to afford extra cellular for progression of vessel lumen. ${ }^{26}$

\section{Mechanism of angiogenesis}

\section{Normal angiogenesis}

In process of vasculogenesis, there is proliferation of angioblasts that merge in embryonic grid of vessels called as capillary plexus (primary). Endothelial cell matrix functions as a gibbet for angiogenesis generated by vasculogenesis. ${ }^{27}$ There is development and splitting of new vessels resulting from pre-existing vessels in angiogenesis once capillary plexus (primary) formed. In embryo where is the most of normal angiogenesis happens and inaugurates primary vascular pyramid and tolerable vasculature to support growth and development of organs Angiogenesis process in adults carried out through ovarian cycle as well as in physiological repair mechanisms like, ${ }^{28}$ healing of wound. ${ }^{29}$ There is minute endothelial cells revenue that happens in adult vasculature. ${ }^{30}$ There are many sundry processes in micro vessels that results in fruition and renovation of newly bent micro vessels, ${ }^{29}$ pericytes should be detached from forking vessel to produce newly blood sprouts. Proteases like matrix metalloproteinases sulliedas well as refashioned extracellular matrix and endothelial cell cellar membrane, thus new matrix produced via stromal cells. ${ }^{31}$ This whole process results the flow of blood in newly synthesized vessels.

\section{Factors regulating normal angiogenesis}

The factors that regulate normal angiogenesis are consists of three main groups including soluble factors, membrane -bound proteins and biomechanical forces. There mechanisms are shown in Table 2a $\& 2 \mathrm{~b}$ below.

Table 2a Factors regulating normal angiogenesis

\begin{tabular}{|c|c|}
\hline Factor & Mechanism \\
\hline \multicolumn{2}{|l|}{ Soluble Factors } \\
\hline & $\begin{array}{l}\text { Impedes endothelial cell apoptosis, Upturns endothelial cell permeability, Enhances endothelial cell migration, Motivates in } \\
\text { vivo angiogenesis, Upturns endothelial cell permeability, Motivates endothelial cell proliferation, Motivates endothelial cell uPA/ } \\
\text { PAI-I production }\end{array}$ \\
\hline \multicolumn{2}{|l|}{ VEGF } \\
\hline & Motivates in vitro endothelial cell sprout formation, Upturns girth and stability of endothelium \\
\hline \multicolumn{2}{|c|}{ Angiopoietin-I (Angl) } \\
\hline \multirow[t]{2}{*}{$\begin{array}{l}\text { Angiopoietin-2 } \\
\text { (Ang2) }\end{array}$} & Destabilizes endothelium Antagonizes Ang I signaling \\
\hline & $\begin{array}{l}\text { Motivates endothelial cell proliferation, Boosts endothelial cell migration, Motivates endothelial cell PA/collagenase production, } \\
\text { Motivates endothelial cell tube formation, Motivates in vivo angiogenesis }\end{array}$ \\
\hline aFGF,bFGF & \\
\hline
\end{tabular}


Table continued...

\begin{tabular}{|c|c|}
\hline Factor & Mechanism \\
\hline & $\begin{array}{l}\text { Motivates DNA synthesis in endothelial cells, Motivates endothelial cells to form chords in vitro, Motivates proliferation of } \\
\text { smooth muscle cells and pericytes, Prompts vWF,VEGF, and VEGF receptor-2 expression in cardiac endothelial cells, Upturns } \\
\text { capillary wall stability }\end{array}$ \\
\hline \multicolumn{2}{|l|}{ PDGF } \\
\hline & $\begin{array}{l}\text { Supports anchorage-independent growth of fibroblasts, Inhibits proliferation and migration of endothelial cells, Motivates/ } \\
\text { inhibits formation of endothelial cell tubes in vitro, Produces net anti proteolytic activity via modulation of uPA/PAI-I } \\
\text { expression levels, Inhibits production of other proteases/stimulates production of protease inhibitors, Motivates VSMA } \\
\text { production by pericytes, Chemotactic for monocytes and fibroblasts, Motivates in vivo angiogenesis in presence of } \\
\text { inflammatory response, Upturns vessel wall stability }\end{array}$ \\
\hline \multicolumn{2}{|l|}{ TGF- $\beta$} \\
\hline & Motivates angiogenesis in vivo, Motivates formation of endothelial cell tubes in vitro, Inhibits endothelial cell proliferation \\
\hline \multicolumn{2}{|l|}{ TNF- $\alpha$} \\
\hline & Motivate endothelial cell proliferation, Motivate angiogenesis in vivo \\
\hline \multicolumn{2}{|l|}{ EGF,TGF- $\alpha$} \\
\hline G-CSF,GM-CSF & Motivate endothelial cell proliferation and migration \\
\hline \multirow[t]{2}{*}{ Angiogenin } & Motivates angiogenesis in vivo, Supports endothelial cell binding and spreading \\
\hline & Motivates random capillary endothelial cell migration, Motivate endothelial cell tube formation, Motivates in vivo angiogenesis \\
\hline \multicolumn{2}{|l|}{ Angiotropin } \\
\hline Tissue Factor & Contributes to development of yolk sac vasculaturel \\
\hline FactorV & Contributes to development of yolk sac vasculature \\
\hline Prostaglandin & Motivates in vivo angiogenesis \\
\hline Nicotinamide & Motivates in vivo angiogenesis \\
\hline Monobutyrin & Motivates in vivo angiogenesis, Motivates endothelial cell migration in vitro \\
\hline
\end{tabular}

Table 2b Factors regulating normal angiogenesis

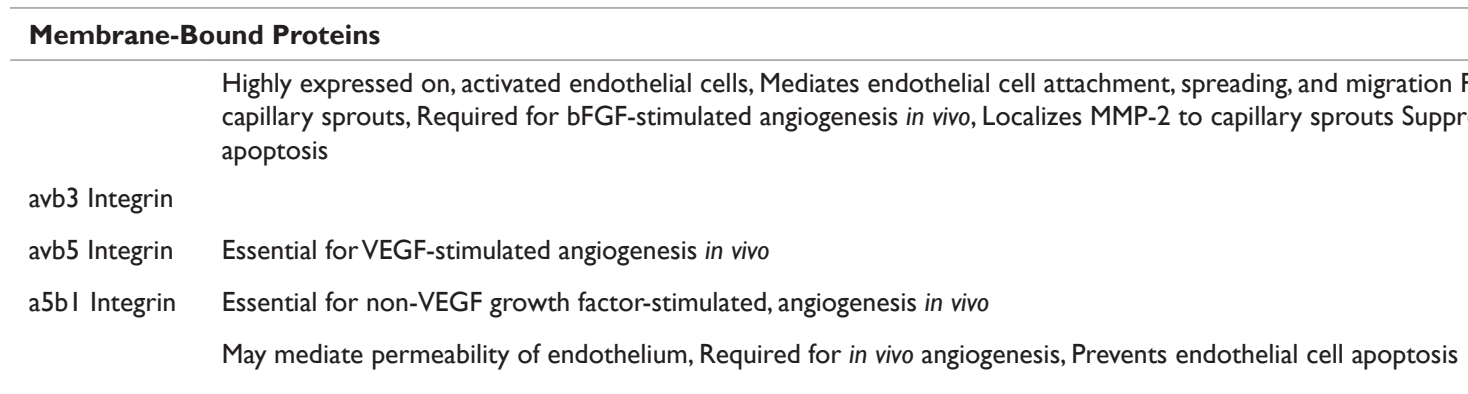

VE Cadherin

At the venous/arterial interfaces of developing embryo, Required for angiogenesis of head and yolk sac and for myocardial trabeculation Eph 4B/Ephrin-B2

Essential for in vivo angiogenesis induced by TNF-a, Chemotactic for endothelial cells in vitro

Ephrin AI

Eph-2A Essential for endothelial cell tube formation in vitro

Biomechanical Forces

Blood Flow/

Shear Stress

\section{Tumor-persuaded angiogenesis}

Tumors are inhabitants of host-imitative cells, which have vanished ability to legalize growth resulting in aberrant proliferate. Yet numerous landscapes differentiate them from non-renovated foils, many features of tumor cells that are analogous to normal ones. ${ }_{32}$ One foremost resemblance is obligation for a sufficient hoard of oxygen as well as nutrients and an operative means to eradicate trashes in mandate for metabolic procedures to befall and being to be conserved. Propinquity to vascular stream fulfills these needs for mammalian cells. Ordinary cells and tissues trust on functional vasculogenesis and angiogenesis to deliver them with vasculature, which fulfills the metabolic needs. ${ }^{32}$ 


\section{Tumor vasculature}

Tumors can begin their personal blood supply by numerous revenues. In tumor-persuaded angiogenesis, a tumor may provoke development of blood vessels resulting from pre-surviving capillaries. Furth more, tumors cells are capable to develop around a surviving vessel and later, at least primarily, do not want to persuade angiogenesis for passable vascularization. ${ }^{33}$ In addition, (CEPs), angioblastidentical cells that result from bone marrow tissue but conveyed to be exist in adult circulation, have freshly been recommended to donate to a tumor-imitated blood vessels. ${ }^{34}$ Among them numerous dearth functional pericytes, ${ }^{35}$ which are distended and elaborated, as well as they are remarkably permanent due to existence of fenestrae and trans-cellular slums and dearth of a thorough basement membrane. ${ }^{36}$ Additionally, walls of tumor may be composed up of endothelial cells as well as tumor cells mutually. ${ }^{37}$ These structural aberrations in tumor's vessels reproduce pathological flora of their generation, however their aptitude to upkeep cell growth may also inspires use of physiological appliances of angiogenesis, which tumors requisition for their propagation (Table 3).32

\section{Working mechanism of chocolate components}

\section{Antioxidant effects}

Reactive oxygen species (ROS) are potential carcinogens that facilitate mutagenesis, tumor promotion and progression. ${ }^{38}$ Food derived products exist universally and are expected to be safe, they are highly interesting for development as chemo preventive agents to treat reactive oxygen free radicals that results in cancer pathogenesis. ${ }^{39,40}$ Natural compounds has the ability to induce cytotoxicity thereby protects against cancer and many researcher's developing chemotherapeutic by based on its ability to induce apoptosis. ${ }^{41-44}$ Well-known character of polyphenols in cocoa is their ability to show there action as antioxidants. Polyphenols (flavones and catechins) are powerful flavonoids for defensive the body alongside reactive oxygen radicals. Cells and tissues of body constantly endangered by the injury affected by free radicals as well as reactive oxygen radicals that are bent in usual oxygen metabolism or are persuaded by exogenous injury. ${ }^{45}$ Sequences and mechanisms of trials thru which free radicals restrict with cellular roles are not entirely known but most significant trial appears to be lipid peroxidation resulting in damage of cellular membrane. This cellular damage causes a shift in the net charge of cell that changes the osmotic pressure, resulting in swelling and ultimately cell death. Free radicals can entice numerous inflammatory mediators, subsidizing to common inflammatory retort and tissue injury. ${ }^{32}$

Living bodies have established numerous effective procedures order to prevent there selves from free oxygen radicals. ${ }^{46}$ Antioxidantdefensive mechanisms of body comprise certain enzymes like; catalase, glutathione peroxidase, and superoxide dismutase, but have no enzymatic foils like; ascorbic acid, tocopherol, and glutathione. Neovascularization that includes angiogenesis is mandatory for advancement of metastasis. ${ }^{32}$

\section{Anti-angiogenesis effects}

Secretion of neovascularization/angiogenesis mediators via mast cells and motivation of mast cell migration by tumor-plagiaristic peptides specify that mast cells can be tangle in metastasis migration of tumor. ${ }^{47-49}$ Persuasive reticence of the mast cell stimulation and propagation by numerous flavonoids can also donate antitumor effects. ${ }^{49}$ The mast cells discharge TNF that persuades molecule expression of endothelial adhesion. ${ }^{49,50}$ There is reduction in stages of plasminogen activators, bFGF induction and their functional inhibitors. $^{51}$ bFGF motivates manufacturing of urokinase-type, plasminogen activator and PAI-1 in vascular-endothelial cells. Plasminogen synthesized plasmin that showing stepwise proteolytic deprivation of matrix protein. This is the key phase in mechanism of neovascularization.

\section{Conclusion}

Components of dark chocolate analytically impulse numerous cellular, immunological and a series of biological measures related with angiogenesis, cancer development and growth, like; the cell proliferation, cell differentiation, apoptosis, and neovascularization. The studies in vitro have recognized a connotation between flavonoidpersuaded impulsion of MMP and protein kinase actions with tumor cell invasion, apoptosis and cellular proliferation conduct. Certain dark chocolate components, such as flavonoids pageant antitumor activity and reduce angiogenesis in vivo.

\section{Acknowledgments}

None.

\section{Conflicts of interest}

The author declares that there is no conflict of interest.

\section{Funding}

None.

\section{References}

1. Jalil AM, Ismail A. Polyphenols in coca and coca products. Is there a link between antioxidants properties and health? Molecules. 2008;13(9):2190-2219.

2. Kelm MA, Johnson JC, Robbins RJ, et al. High-performance liquid chromatography separation and purification of cacao (Theobroma cacao L) procyanidins according to degree of polymerization using a diol stationary phase. J Agric Food Chem. 2006;54(5):1571-1576.

3. Rios LY, Gonthier MP, Remesy C, et al. Chocolate intake increases urinary excretion of polyphenol-derived phenolic acids in healthy human subjects. Am J Clin Nutr. 2003;77(4):912-918.

4. Holash J, Maisonpierre PC, Compton D, et al. Vessel cooption, regression, and growth in tumors mediated by angiopoietins and VEGF. Science. 1999;284(5422):1994-1998.

5. Banerjee N, Kim H, Talcott S, et al. Pomegranate polyphenolics suppressed azoxymethane-induced colorectal aberrant crypt foci (ACF) and inflammation:possible role of miR-126/VCAM-1 and miR-126/ PI3K/AKT/mTOR. Carcinogenesis. 2013;34(12):2814-2822.

6. Wang LM, Xie KP, Huo HN, et al. Luteolin inhibits proliferation induced by IGF-1 pathway dependent ER $\alpha$ in human breast cancer MCF-7 cells. Asian Pac J Cancer Prev. 2012;13(4):1431-1437.

7. Turini ME, DuBois RN. Cyclooxygenase-2: a therapeutic target. Annu Rev Med. 2002;53:35-57.

8. Hamiza OO, Rehman MU, Tahir M, et al. Amelioration of 1,2dimethylhydrazine (DMH) induced colon oxidative stress, inflammation and tumor promotion response by tannic acid in Wistar rats. Asian Pac J Cancer Prev. 2012;13(9):4393-4402.

9. Ultee AJ, Dorsen V. Bijdrage tot de kennis der op Java gecultiveerdecacaosooten. In Java Agric Station Report. 2006;41:28-32.

10. Adam WB, Hardy F, Nierenstein M. The catechin of the cocoa bean. $J$ Am Chem Soc. 1931;53:727-728. 
11. Freudenberg K, Cox RFB, Braun E. The catechin of the cacao bean. $J$ Am Chem Soc. 1932;54:1913-1917.

12. Forsyth WG. Cacao polyphenolic substances. 3. Separation and estimation on paper chromatograms. Biochem J. 1955;60(1):108-111.

13. Cooper KA, Campos-Giménez E, Jiménez Alvarez D, et al. Rapid reverse-phase ultra-performance liquid chromatography analysis of the major cocoa polyphenols and inter-relationship of their concentration in chocolate. J Agric Food Chem. 2007;55(8):2841-2847.

14. Verstraeten SV, Oteiza PI, Fraga CG. Membrane effects of cocoa procyanidins in liposomes and Jurkat T cells. Biol Res. 2004;37(2):293300 .

15. Hammerstone JF, Lazarus SA, Mitchell AE, et al. Identification of procyanidins in cocoa (Theobromacacao) and chocolate using highperformance liquid chromatography/ mass spectrometry. J Agric Food Chem. 1999;47(2):490-496.

16. Smit, HJ, Blackburn RJ. Reinforcing effects of caffeine and theobromine as found in chocolate. Psychopharmacology (Berl). 2005;181(1):101106.

17. Timbie DJ, Sechrist L, Kenney PG. Application of HPLC to the study of variables affecting theobromine and caffeine concentrations in cocoa beans. J Food Sci. 1978;43(2):560-562.

18. Barcz E, Sommer E, Sokolnicka I, et al. The influence of theobromine on angiogenic activity andproangiogenic cytokines production of human ovarian cancer cells. Oncol Rep. 1998;5(2):517-520.

19. Biethl B, Wewetzer C, Passern D. Vacuolar (storage) proteins of cocoa seeds and their degradation during germination and fermentation. $J$ Sci Food Agri. 1982;33:1291-1304.

20. Voigt J, Heinrichs H, Voigt G, et al. Cocoa specific aroma precursors are generated by proteolytic digestion of the vicilin-like globulin of cocoa seeds. Food Chem. 1994;50(2):177-184.

21. Zak DK, Keeney PG. Changes in cocoa proteins during ripening of fruit, fermentation, and further processing of cocoa beans. J Agric Food Chem. 1976 24(3):483-486.

22. Rubanyi GM. Angiogenesis in health and disease. M Dekker Inc., Basel, New York, USA; 2000.

23. Voigt J, Biehl B, Kamaruddin SW. The major seed proteins of Theobroma cacao. L. Food Chem. 1993;47(2):145-151.

24. Kornowski R, Epstein SE, Leon MB. Handbook of myocardial revascularization and angiogenesis. Martin Dunitz Ltd., London, UK; 2000 .

25. Stegmann TJ. New Vessels for the Heart. Angiogenesis as New Treatment for Coronary Heart Disease:The Story of its Discovery and Development. Cardio Vascular Bio Therapeutics Inc., NevadaHenderson, USA; 2004.

26. Laham RJ, Baim DS. Angiogenesis and direct myocardial revascularization. Humana Press Totowa, New York, USA;; 2005. pp. $1-357$.

27. Risau W. Mechanisms of Angiogenesis. Nature. 1997;386(6626):671674.

28. Folkman J. Angiogenesis in Cancer, Vascular, Rheumatoid, and Other Disease. Nature Med. 1995;1:27-31.

29. Klagsbrun M, D’Amore PA. Regulators of Angiogenesis. Annu Rev Physiol. 1991;53:217-239.

30. Denekamp J. Endothelial cell proliferation as a novel approach to targeting tumour therapy. Br J Cancer. 1982;45(1):136-139.

31. Moses MA. The Regulation of Neovascularization of Matrix Metalloproteinases and their Inhibitors. Stem Cells. 1997;15(3):180 189.
32. Papetti M, Herman IM. Mechanisms of Normal and Tumor-Derived Angiogenesis. Am J Physiol Cell Physiol. 2001;282(5):C947-C970.

33. Holash J, Maisonpierre PC, Compton D, et al. Vessel cooption, regression, and growth in tumors mediated by angiopoietins and VEGF. Science. 1999;284(5422):1994-1998.

34. Rafii S. Circulating endothelial precursors: mystery, reality, and promise. J Clin Invest. 2000;105(1):17-19.

35. Benjamin LE, Golijanin D, Itin A, et al. Selective ablation of immature blood vessels in established human tumors follows vascular endothelial growth factor withdrawal. J Clin Invest. 1999;103(2):159-165.

36. Carmeliet P, Jain RK. Angiogenesis in cancer and other diseases. Nature. 2000;407(6801):249-257.

37. Chang YS, di Tomaso E, McDonald DM, et al. Mosaic blood vessels in tumors: frequency of cancer cells in contact with flowing blood. Proc Natl Acad Sci U S A. 2000;97(26):14608-14613.

38. Khan SU, Mahjabeen I, Malik FA, et al. Prognostic Significance of Altered Blood and Tissue Glutathione Levels in Head and Neck Squamous Cell Carcinoma Cases. Asian Pac J Cancer Prev. 2014;15(18):7603-7609.

39. Sengupta A, Ghosh S, Das S. Inhibition of cell proliferation and induction of apoptosis during azoxymethane induced colon carcinogenesis by black tea. Asian Pac J Cancer Prev. 2002 3(1):41-46.

40. Chihara T, Shimpo K, Kaneko T, et al. Inhibition of 1, 2dimethylhydrazine-induced mucin-depleted foci and O6-methylguanine DNA adducts in the rat colorectum by boiled garlic powder. Asian Pac J Cancer Prev. 2010;11(5):1301-1304.

41. Sriram N, Kalayrasan S, Ashok kumar P, et al. Diallyl sulfide induces apoptosis in Colo 320 DM human colon cancer cells:involvement of caspase-3, NF- $\mathrm{KB}$, and ERK. Mol Cell Biochem. 2008;311(1-2):157165.

42. Acebedo AR, Amor EC, Jacinto SD. Apoptosis-inducing activity of HPLC fraction from Voacangaglobosa (Blanco) merr. on the human colon carcinoma cell. Asian Pac J Cancer Prev. 2014;15(2):617-622.

43. Shafie NH, Mohd Esa N, Ithnin H, et al. Preventive Inositol hexaphosphate extracted from rice bran inhibits colorectal cancer through involvement of $\mathrm{Wnt} / \beta$-catenin and $\mathrm{COX}-2$ pathways. Biomed Res Int. 2013;2013:681027.

44. Zou X, Liu SL, Zhou JY, et al. Beta-asarone induces LoVo colon cancer cell apoptosis by up-regulation of caspases through a mitochondrial pathway in vitro and in vivo. Asian Pac J Cancer Prev. 2012;13(10):5291-5298.

45. Grace PA. Ischaemia-reperfusion injury. Br J Surg. 1994;81(5):637647.

46. Halliwell B. How to characterize an antioxidant:an update. Biochem Soc Symp. 1995;61:73-101.

47. Poole TJ, Zetter BR. Stimulation of rat peritoneal mast cell migration by tumor-derived peptides. Cancer Res. 1983;43(12 Pt 1):5857-5861.

48. Scott KG. The mast cell, its amines, and tumor growth in rodents and man. Ann N Y Acad Sci. 1963;103:285-312.

49. Theoharides TC. Neuroimmunology of tumor growth:the role of mast cells. Int J Immunopathol Pharmacol. 1963;1:89-98.

50. Anné S, Agarwal R, Nair MP. Inhibition of endotoxins induced expression of intercellular adhesion molecule-1 and of leukocyte adhesion to endothelial cells by the plant flavonoid quercetin. $J$ Allergy Clin Immunol. 1994;93:276.

51. Kim MH. Flavonoids inhibit VEGF/bFGF-induced angiogenesis in vitro by inhibiting the matrix-degrading proteases. $J$ Cell Biochem. 2003;89(3):529-538. 